\title{
Electrocatalytic Hydrogen Evolution Reaction Using meso- tetrakis-(pentafluorophenyl)porphyrin iron(III) chloride
}

\author{
Khalaf Alenezi \\ Department of Chemistry, Faculty of Science, University of Hail, Hail, Kingdom of Saudi Arabia. \\ E-mail: k.alenezi@uoh.edu.sa \\ doi: $10.20964 / 2017.01 .58$
}

Received: 24 April 2016 / Accepted: 12 October 2016 / Published: 12 December 2016

This study focuses on the electrochemical catalysis of proton reduction into hydrogen using mesotetrakis-(pentafluorophenyl)porphyrin iron(III) chloride in the presence of $\mathrm{Et}_{3} \mathrm{NHCl}$. Indeed, the direct reduction of $\mathrm{Et}_{3} \mathrm{NHCl}$ on vitreous carbon electrode occurs at $\mathrm{E}_{\mathrm{p}}-1.6 \mathrm{~V}$ vs $\mathrm{Ag} / \mathrm{AgCl}$ in $\left[\mathrm{Bu}_{4} \mathrm{~N}\right]\left[\mathrm{BF}_{4}\right]-$ $\mathrm{CH}_{3} \mathrm{CN}$, whereas the reduction potential shifts to $-1.3 \mathrm{~V}$ vs $\mathrm{Ag} / \mathrm{AgCl}$ in the presence of $\mathrm{Fe}(\mathrm{PFTPP}) \mathrm{Cl}$. Based on the gas chromatography analysis, the formation of $\mathrm{H}_{2}$, with a current efficiency of $c a$. $58 \%$ after $3.8 \mathrm{~h}$, is achieved with a yield of $8 \mu$ moles and a turnover number of 8 while the chemical yield was about $80 \%$. These results reflect the effect of the presence of electron withdrawing pentafluorophenyl groups around the metal in Fe(PFTPP)Cl.

Keywords: electrocatalysis; hydrogen; iron complex, porphyrin

\section{$\underline{\text { FULL TEXT }}$}

(C) 2017 The Authors. Published by ESG (www.electrochemsci.org). This article is an open access article distributed under the terms and conditions of the Creative Commons Attribution license (http://creativecommons.org/licenses/by/4.0/). 